\title{
Screening for quality indicators and phenolic compounds of biotechnological interest in honey samples from six species of stingless bees (Hymenoptera: Apidae)
}

\author{
Rosane Gomes de OLIVEIRA ${ }^{1 *}$, Sona JAIN ${ }^{1}$, Alexandre Cândido LUNA ${ }^{1}$, Lisiane dos Santos FREITAS ${ }^{1}$, \\ Edilson Divino de ARAÚJO ${ }^{1}$
}

\begin{abstract}
Honey from stingless bees of the genus Melipona is a well sought product. Nevertheless lack of legal frameworks for quality assessment complicates the evaluation of food safety and marketing of these products. Seeking to assess the quality of honey from the bees of this genus, physical and chemical analyses, identification of phenolic compounds, and microbiological evaluation from six species of stingless bees was performed. The honey samples showed high reducing sugars, low protein levels and a balanced microbiota. High total phenols and flavonoids and higher antioxidant activity were also recorded. Different phenolic compounds of great biotechnological potential were identified and of these apigenin, kaempferol and luteolin were identified for the first time in honey. To the best of our knowledge, this is one of the few works describing a detail characterization of melipona honey together with identification of the phenolic compounds of significant therapeutic value.
\end{abstract}

Keywords: honey; chromatography; flavonoids; phenols; antioxidants; stingless bees; pollen types.

Practical Application: This is one of the few works that describe the characterization of honey from seven species of stingless bees together detailing the identification of phenolic compounds of significant therapeutic value, which can serve as an important reference for future studies.

\section{Introduction}

Despite the lack of standardized legal frameworks for quality assessment, honey produced by eusocial bees of the genus Melipona is a product that has shown increasing demand, and even attracted higher prices than the honey produced by bees of the genus Apis mellifera (Alves et al., 2005), due to its peculiar flavor, nutritional value, and therapeutic properties (Silva et al., 2013a; Kumul et al., 2015; Kadri et al., 2016).

Honey is reported to prevent the onset of various pathological processes in the human body; such as atherosclerosis, cardiovascular disease and Alzheimer's as well as giardiasis (Mohammed et al., 2015) It has also shown to possess anti-stress, anticarcinogenic (Muhammad et al., 2015) and antibacterial (Nishio et al., 2014) properties. The medicinal properties of honeys are associated with their antioxidant activity which are linked to the phenolic compounds present in the honey samples which may vary depending on the floral source, storage, geography and species of the bees (Liu et al., 2012; Cimpoiu et al., 2013).

Most studies describing the physical and chemical composition of honeys have been conducted for the honey produced by the genus Apis, requiring more studies that reference these properties in honey produced by bees of the genus Melipona (Alves et al., 2005; Silva et al., 2013a, b). In Brazil, the only two studies published with Melipona honey (Michmelia seminigra merrillae and Melipona subnitida) report good antioxidant capacity in the honey produced by this species and relate it to the high concentration of phenolic compounds found in the honey samples (Silva et al., 2013a, b).

To verify if the honey has adequate nutritional quality for consumption and antioxidant capacity, physiochemical, and microbiological analysis, and the identification of phenol compounds are extremely important, since each type of honey has its own physicochemical characteristic and complex chemistry that needs to be assessed mainly in species of stingless bees where the studies are less frequent (Silva et al., 2013b).

The goal of this study was to evaluate the quality of seven honey samples from six different species of the genus Melipona through physicochemical, chromatographic, and microbiological analysis. To the best of our knowledge this is one of the few studies detailing the analysis and identification of phenolic compounds from melipona honey.

\section{Materials and methods}

\subsection{Honey samples}

The honey samples were collected during the month of May 2013 from six species of Melipona stingless bees housed in rational boxes. The total of seven samples were analyzed in triplicate from the species Melipona quadrifasciata Lepetellier 1836 (two subspecies Melipona q. quadrifasciata and Melipona q. anthidioides), Melipona asilvai Moure 1971, Melipona subnitida 
Ducke,1910 and Melipona scutellaris Latreille 1811, from meliponary in São Cristovão city, Sergipe state ( $11^{\circ} 00^{\prime} 54^{\prime \prime}$, $\left.37^{\circ} 12^{\prime} 21^{\prime \prime} \mathrm{W}\right) ;$ Melipona compressipes Smith 1854 from meliponary

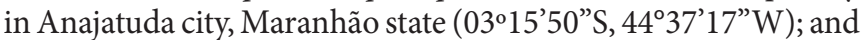
Melipona mandacaia Smith 1863, from meliponary in Irecê city, Bahia state ( $\left.11^{\circ} 18^{\prime} 14^{\prime \prime} \mathrm{S}, 41^{\circ} 51^{\prime} 21^{\prime \prime} \mathrm{W}\right)$. The honey samples were collected in sterile $50 \mathrm{~mL}$ falcon tubes and stored in the freezer at $-20{ }^{\circ} \mathrm{C}$ until analysis.

\subsection{Chemicals and reagents}

DPPH (1.1-difhenyl-2-picril-hidrazyl), potassium persulfate, ascorbic acid, ethylene diaminetetra acetic acid (EDTA), and formic acid were acquired from Vetec (Sigma-Aldrich/Brazil), and methanol was bought from Tedia, Brazil.

The standards used for the liquid chromatography were: apigenin, kaempferol, luteolin, quercetin, and narigerin all bought from Sigma-Aldrich. The acids: ferulic, caffeic, p-coumaric, chlorogenic, abscisic, protocatechuic, vanillic, trans-cinnamic, gallic, and Folin-Ciocalteu's phenol reagent were also acquired from Sigma-Aldrich. All chemicals used were of analytical grade.

\subsection{Physicochemical, phenols and flavonoids evaluation}

The analysis of reducing sugars was carried out as described in AOAC (Association of Official Analytical Chemists, 1995) and the evaluation of the total protein content was performed by the method described in AACC (American Association of Cereal Chemists, 2000).

The total phenolic content was estimated using the spectrometric method of Folin-Ciocalteu' as described by Beretta et al. (2005). The total flavonoid content was determined according to the methodology described by Meda et al. (2005) and Ahn et al. (2007).

\subsection{DPPH analysis, phenolic compounds extraction and HPLC-DAD}

To analyze the antioxidant activity standard protocol for 2.2-diphenyl-2-picrylhydrazyl (DPPH) by Brand-Williams et al. (1995) and Tominaga et al. (2005) was utilized. Radical DPPH was quantified by spectrophotometry with absorption at 517 $\mathrm{nm}$. The inhibition coefficient $\left(\mathrm{IC}_{50}\right)$ and antiradical efficiency $\left(\mathrm{EC}_{50}\right)$ were carried out following the protocol by Kulisic et al. (2006).

The extraction of phenolic compounds was carried out using the methods described by Andrade et al. (1997) and Ferreres et al. (1996) using $10 \mathrm{~g}$ of honey dissolved in $50 \mathrm{~mL}$ of methanol. Due to the presence of sugars in honey, the samples were subjected to additional Amberlite XAD-2 treatment. The chromatographic separation of the samples with HPLC-DAD was conducted using chromatograph Prominence Shimadzu (Quioto, JAPÃO) equipped with diode array detector (SPDM2O), a reverse phase column Phenomenex Luna C18 (250 mm x $4.6 \mathrm{~mm}$ x $5 \mathrm{~mm}$ ), precolumn Phenomenex C18 (4 $\mathrm{mm} \times 3 \mathrm{~mm}$, with a temperature of $\left.30^{\circ} \mathrm{C}\right)$, and an oven $\left(\right.$ at $\left.35^{\circ} \mathrm{C}\right)$. The mobile phase consisted of a mixture of $1 \%$ aqueous formic acid (A) and methanol (B) with a flow rate of $1 \mathrm{~mL} / \mathrm{min}$ using the solvent gradient: $0-10 \mathrm{~min} 10 \%$ of $\mathrm{B}, 10-40 \mathrm{~min} 55 \%$ of $\mathrm{B}, 40-46 \min 55 \%$ of $\mathrm{B}, 46-60 \min 75 \%$ of $\mathrm{B}, 60-65 \mathrm{~min} 75 \%$ of $\mathrm{B}, 65-68 \mathrm{~min} 10 \%$ of $\mathrm{B}$, and $68-70 \mathrm{~min}$ $10 \%$ of $\mathrm{B}$. The injection volume was $20 \mu \mathrm{L}$. The identification of phenolic compounds was based on the retention time and $\mathrm{UV} /$ Vis spectra scan ( $245 \mathrm{~nm}$ to $370 \mathrm{~nm}$ ) which was compared to analytical standards. The gallic, abscisic, and trans-cinnamic acids were evaluated at $270 \mathrm{~nm}$; protocatechuicacid, vanillic acid, luteolin, narigerin, and apigenin at $290 \mathrm{~nm}$; chlorogenic, p-coumaric, and feluric acids at $310 \mathrm{~nm}$; quercetin, caffeic acid, rutin, and kaempferol at $370 \mathrm{~nm}$.

\subsection{Botanical origin}

For the identification of botanical origin protocols described by Erdtman (1952) and Louveaux et al. (1978) were used. The slides were observed under optical microscope and 1000 pollens were counted from each sample for quantitative analysis. The pollens were grouped in four classes: predominant pollen $(>45 \%)$, accessory pollen $(\leq 45 \%$ to $>15 \%)$, important pollen ( $\geq 3 \%$ to $\leq 15 \%)$, and minority pollen $(<3 \%)$. To identify the families and pollen types, catalagos of taxonomic and morphological reference indicated by several authors were utilized (Barth, 1989, 2004).

\subsection{Isolation and identification of microorganisms}

Plate count agar (PCA) and Dicloran rose bengal chloramphenicol agar (DRBC) were used for the growth of microorganisms. $100 \mu \mathrm{L}$ of diluted honey sample $\left(10^{-2}, 10^{-3}, 10^{-4}, 10^{-5}\right)$ was plated on PCA to evaluate Mesophilic aerobic (incubated at $37 \pm 1{ }^{\circ} \mathrm{C}$ for $48 \pm 2$ hours) and psychotropic aerobic microorganisms (incubated at $17 \pm 1{ }^{\circ} \mathrm{C}$ for 16 hours and kept refrigerated at $4{ }^{\circ} \mathrm{C}$ for five days). DRBC was used to evaluate the yeasts and mold (incubated at $25 \pm 3^{\circ} \mathrm{C}$ for five days).

The microorganisms were microscopically and morphologically observed and the total number of microorganisms counted per plate was expressed as colony-forming unit per gram (CFU/g) (Silva et al., 2010).

Identification of the microorganisms was performed by the amplification of their total DNA by PCR, sequencing of the PCR amplified band and on line database comparison of the sequenced DNA with other similar DNA sequences present in the GeneBank. For PCR amplification and DNA sequencing, primers corresponding to $16 \mathrm{~S}$ ribosomal DNA were utilized for bacteria (Lane, 1991). For the amplification and sequencing of the yeast and fungi ITS primers (Bellemain et al., 2010) were utilized.

Overnight cultures of single pure colonies in nutrient broth were used for DNA extraction according to the protocol of Moreira et al. (2010). DNA quantification was performed using Qubit (Invitrogen ${ }^{\circledR}$ ). PCR was carried out in a final volume of $20 \mu \mathrm{L}$ with $2 \mu \mathrm{L}$ of each $10 \mu \mathrm{M}$ primer (16S-5'AGAGTTTGATCMTGGCTAG-3'F, 5'TACGGYTACCT TGTTACGACTT-3'R; ITS-5'TCCGTAGGTGAACCTGCG-3'F, 5'GCTGCGTTCTTCATCGATGC-3'R), $8.5 \mu \mathrm{L}$ Taq Master Mix RED (Amplicon ${ }^{\circledR}$ ), $8.5 \mu \mathrm{L}$ ultra-pure water, and $1 \mu \mathrm{L}$ of $20 \mathrm{ng} / \mu \mathrm{L}$ extracted DNA. PCR was performed using Promega ${ }^{\circledR}$ TC96CG thermocycle using the following conditions: hold of $94{ }^{\circ} \mathrm{C}$ for 
5 minutes, followed by 40 cycles of denaturation at $94{ }^{\circ} \mathrm{C}$ for 30 seconds, annealing at $54^{\circ} \mathrm{C}$ for 30 seconds and extension at $74{ }^{\circ} \mathrm{C}$ for 45 seconds. In the end a final extension at $74{ }^{\circ} \mathrm{C}$ for 10 minutes was carried out. Electrophoresis was performed on $0.8 \%$ agarose gel and stained with Sybr Green (Qiagen ${ }^{\circledR}$ ).

Amplified DNA was purified using Wizard ${ }^{\circledR}$ SV Gel Kit and PCR Clean-Up System (Promega ${ }^{\circledR}$ ) and sequenced using BigDye $^{\circledR}$ Terminator v.3.1 Cycle Sequencing kit and ABI 3500 sequencer (Applied Biosystem).

The quality of the sequences was verified using the Staden Package Version 2.0 (Staden et al., 2001). Only sequences with phred values above 30 were considered for subsequent analysis. The 16S and ITS1-ITS2 gene sequences were aligned using the ClustalW algorithm embedded in the software MEGA (Molecular Evolutionary Genetics Analysis) version 6.0.5 (Tamura et al., 2007).

After alignment the sequences were inserted into BLAST (Basic Local Alignment Search Tool) and compared to the sequences present in the GenBank.

\subsection{Statistical analysis}

Analyses of all seven samples were performed in triplicate. The averages were compared by Tukey' test ( $\mathrm{p} \leq 0.05)$ using Assistat software (Statistics Assistance 7.6 beta version).

\section{Results and discussion}

The results of physico-chemical analysis obtained from the honey samples are presented in (Table 1). The samples showed satisfactory reducing sugar content varying between $34.83 \%$ and $78.95 \%$. There is still no legislation regulating the quality of honey produced by stingless bee. Previously reported levels of reducing sugars in Meliponini range from 50.60\% to 95.60\% (Alves et al., 2005). In this study, the lowest level of sugar was observed in honey from Melipona mandacaia. Low sugars are indicative of immature honey (Alves et al., 2005) and in the case of Melipona, are connected to fermentation by bacteria. The protein content ranged between 0.12 to $0.39 \mathrm{mg} / 100 \mathrm{~g}$ (Table 1 ).

Honey generally haslow protein content, and the variation in the protein contentis related to the botanical origin of the nectar collected by bees (Noor et al., 2014).

The honey produced by stingless bees has been reported to possess high total phenol content and consequently higher antioxidant capacity compared to other types of honeys
(Noor et al., 2014).The total phenols present in the honey samples ranged from 30.71 (Melipona compressipes) to 854.02 (Melipona subnitida) mg/100 g of Gallic acid equivalent (GAE) (Table 1) which were higher compared to honeys of Melipona seminigramerrilae, stingless bees from Amazônia (Northern Brazil), with 17 to $66 \mathrm{mg} / \mathrm{g}$ of GAE (Silva et al., 2013a). High total flavonoids content, ranging from 30.24 (Melipona scutellaris) to 279.73 (Melipona subnitida) $\mathrm{mg} / 100 \mathrm{~g}$ of equivalent of quercetin (EQA) (Table 1) were found in all the honey samples analyzed in this study. It is believed that the flavonoids in honey are partially derived from flavonoids in pollens resulting from enzymatic hydrolysis of substances contained in the bee saliva (Anklam, 1998). The levels of flavonoids were also variable according to the species of bees and plants visited by these bees.

The antioxidant activity measured by the DPPH method $\left(\mathrm{EC}_{50}\right)$ showed values ranging from 25.39 (Melipona q. quadrifasciata) to 51.44 (Melipona scutellaris) $\mathrm{mg} / \mathrm{mL}$ (Table 1). The flavonoids which usually exists in larger quantities than phenols and the others compounds are responsible for much of the antioxidant activity of honey (Alvarez-Suarez et al., 2010).

In this study three important flavonoids were identified as major compounds for the first time in the honey samples from stingless bee: kaempferol in honey samples from Melipona subnitida (160.85 mg/100 g), Melipona q.anthidioides (29.34 mg/100 g), and Melipona scutellaris (6.79 mg/100 g), apigenin in Melipona q. anthidioides (42.15 mg/100 g) and M. mandacaia $(29.34 \mathrm{mg} / 100 \mathrm{~g})$ and luteolin in honeys from Melipona q. quadrifasciata (47.87 mg/100 g) and Melipona asilvai (41.78 mg/100 g (Table 2).

Both apigenin and kaemferol flavonoids are valuable antioxidants and have relevant anticarcinogenic activity (Kukongviriyapan et al., 2006). The chemoprevcntive action of multiflorais honey has been proven by Moskwa et al. (2014). However further studies are necessary in case of melipona honey. Identification of kaemferol and apigenin, in melipona honey suggests that they might have chemopreventive action.

Luteolin is known to promote cell death by apoptosis and preservation of normal cells and also possesses significant anticancer properties (Chen \& Chen, 2013; Dang et al., 2015; Zheng et al., 2014). Its presence in honey produced by Melipona q. anthidoides and Melipona mandacaia might attribute cell protecting properties.

Table 1. Average values of physico-chemical analysis of honey from six species of stingless bees.

\begin{tabular}{|c|c|c|c|c|c|c|c|}
\hline \multirow[b]{2}{*}{ Physicochemical tests } & \multicolumn{7}{|c|}{ Species } \\
\hline & $\begin{array}{c}\text { Melipona } \\
\text { asilvai }\end{array}$ & $\begin{array}{l}\text { Melipona q. } \\
\text { anthidioides }\end{array}$ & $\begin{array}{c}\text { Melipona q. } \\
\text { quadrifasciata }\end{array}$ & $\begin{array}{c}\text { Melipona } \\
\text { mandacaia }\end{array}$ & $\begin{array}{l}\text { Melipona } \\
\text { scutellaris }\end{array}$ & $\begin{array}{c}\text { Melipona } \\
\text { compressipes }\end{array}$ & $\begin{array}{l}\text { Melipona } \\
\text { subnitida }\end{array}$ \\
\hline Reducing sugars (g/100 g) & $63.39 \pm 1^{b}$ & $65.60 \pm 0.3^{b}$ & $60.63 \pm 0.05^{c}$ & $34.83 \pm 1.2^{\mathrm{d}}$ & $64.20 \pm 1.01^{\mathrm{b}}$ & $78.95 \pm 0.05^{\mathrm{a}}$ & $64.20 \pm 0.2^{b}$ \\
\hline Protein $\mathrm{g} / 100 \mathrm{~g}$ & $0.39 \pm 0.01^{\mathrm{a}}$ & $0.12 \pm 0.02^{\mathrm{e}}$ & $0.32 \pm 0.02^{\mathrm{b}}$ & $0.24 \pm 0.04^{c}$ & $0.19 \pm 0.005^{\mathrm{cd}}$ & $0.18 \pm 0.01^{\mathrm{de}}$ & $0.13 \pm 0.011^{\mathrm{ef}}$ \\
\hline Total phenols mg GAE/g & $82.91 \pm 1^{\mathrm{d}}$ & $161.8 \pm 3.4^{c}$ & $82.19 \pm 1.2^{\mathrm{e}}$ & $61.72 \pm 1.1^{\mathrm{f}}$ & $192.01 \pm 2.8^{\mathrm{b}}$ & $30.71 \pm 2.01^{\mathrm{g}}$ & $854.62 \pm 3.8^{\mathrm{a}}$ \\
\hline Total flavonoid mg QE/g & $79.73 \pm 1.6^{b}$ & $43.09 \pm 2^{\mathrm{f}}$ & $75.45 \pm 2.71^{\mathrm{c}}$ & $45.42 \pm 2^{\mathrm{d}}$ & $30.24 \pm 2^{g}$ & $44.63 \pm 2.3^{\mathrm{e}}$ & $279.73 \pm 4.6^{\mathrm{a}}$ \\
\hline $\mathrm{DPPH}\left(\mathrm{IC}_{50} \mathrm{mg} / \mathrm{mL}\right)$ & $41.33 \pm 0.9^{\mathrm{b}}$ & $40.03 \pm 0.4^{c}$ & $25.39 \pm 0.5^{\mathrm{f}}$ & $28.1 \pm 0.6^{\mathrm{e}}$ & $51.44 \pm 0.7^{\mathrm{a}}$ & $37.79 \pm 1.2^{\mathrm{d}}$ & $37.69 \pm 1^{\mathrm{d}}$ \\
\hline
\end{tabular}

Each sample was analysed in triplicate. Values on the same line followed by the same letter are not significantly different ( $\mathrm{p} \leq 0.05)$ by the Tukey's test. 
All honey samples analyzed showed the presence of abscisic acid and gallic acid. And these two phenolic compounds were seen as the major compound in honey samples of Melipona subnitida; Melipona scutellaris and Melipona q. anthidioides, (Table 2). Abscisic acid is also a plant hormone involved in physiological regulation and according to Kenjeric et al. (2008) can be found in varying amounts in honey samples.

The variation of phenol compounds in the honey samples in this study can be related to the floral preference of each species of bees, as shown in Table 3. In the analysis of pollen types, it was possible to verify the presence of 14 different plant families. Those belonging to Fabaceae (subfamily Mimosaceae) Myrtacea, Euphorbiaceae and Solanaceae, were most frequented by the stingless bees which is consistent with many other surveys carried out in the North and Northeast regions of Brazil (Muniz \& Brito, 2007).

The presence of microorganisms in the honey can be explained by what is considered the primary sources of contamination: bee's intestinal flora, soil, water, air, pollen, and nectar. These sources of contamination are practically impossible to avoid because they are naturally occurring. However, hygiene, handling, and packaging of honey are controllable processes which are considered secondary sources of contamination (Różańska \& Osek, 2012). Therefore, the aerobic microorganisms are indicators of the degree of deterioration of products and can help determine the useful shelf-life of these products (Franco \& Landgraf, 2008). Both yeast and bacteria (Table 4) belonging to different genera were found in all the samples under study, similar to ones described before in honey (Giraldo et al., 2013). It is believed that the amounts of microorganisms in honey are lower than in any other natural food due to their high sugar concentration (Giraldo et al., 2013). In addition to this factor, the presence of phytochemical molecules such as phenols, terpenes, and pinocembrine helps control the growth of microorganisms in honeys (Al-Hind, 2005; TorresGonzález et al., 2016).

Table 2. Phenolic compounds profile by HPLC-DAD.

\begin{tabular}{|c|c|c|c|c|c|c|c|}
\hline \multirow{2}{*}{$\begin{array}{c}\text { Phenolic } \\
\text { compounds }\end{array}$} & \multicolumn{7}{|c|}{ Species } \\
\hline & Melipona asilvai & $\begin{array}{l}\text { Melipona q. } \\
\text { anthidioides }\end{array}$ & $\begin{array}{c}\text { Melipona } \\
\text { q.quadrifasciata }\end{array}$ & $\begin{array}{c}\text { Melipona } \\
\text { mandacaia }\end{array}$ & $\begin{array}{l}\text { Melipona } \\
\text { scutellaris }\end{array}$ & $\begin{array}{c}\text { Melipona } \\
\text { compressipes }\end{array}$ & $\begin{array}{l}\text { Melipona } \\
\text { subnitida }\end{array}$ \\
\hline Apigenin & - & - & - & $29.34 \pm 0.57$ & - & - & $42.15 \pm 0.47$ \\
\hline Kaempferol & - & $26.28 \pm 0.37$ & - & - & $6.79 \pm 0.25$ & - & $160.85 \pm 0.93$ \\
\hline Luteolin & $41.78 \pm 1.14$ & - & $47.87 \pm 0.91$ & - & - & - & - \\
\hline Quercetin & - & - & - & - & $1.4 \pm 0.01$ & - & - \\
\hline Naringenin & - & - & - & $5.92 \pm 0.45$ & - & - & - \\
\hline Rutin & - & - & - & - & - & - & - \\
\hline Gallic acid & $1.35 \pm 0.2$ & $0.76 \pm 0.06$ & $1.06 \pm 0.04$ & $1.83 \pm 0.37$ & $1.39 \pm 0.01$ & $2.43 \pm 0.32$ & $1.31 \pm 0.02$ \\
\hline Feluric acid & - & - & - & - & - & & - \\
\hline Caffeic acid & - & - & $122.18 \pm 1.9$ & - & - & $25.83 \pm 0.45$ & $35.82 \pm 0.78$ \\
\hline P-cumaric acid & $3.8 \pm 0.67$ & $7.06 \pm 0.89$ & $3.06 \pm 0.89$ & $7.91 \pm 0.88$ & - & $6.27 \pm 0.42$ & $37.03 \pm 0.51$ \\
\hline
\end{tabular}

Table 3. Frequency and type pollen found in seven samples honey analyzed in this study. 1000 pollen were counted for each sample. Predominant pollen $>45 \%$, accessory pollen $\leq 45 \%$ to $>15 \%$, important pollen $\geq 3 \%$ to $\leq 15 \%$, and minority pollen $<3 \%$.

\begin{tabular}{|c|c|c|c|c|c|c|c|c|}
\hline & & $\begin{array}{c}\text { Melipona } \\
\text { asilvai }\end{array}$ & $\begin{array}{l}\text { Melipona q. } \\
\text { anthidioides }\end{array}$ & $\begin{array}{c}\text { Melipona } \\
\text { compressipes }\end{array}$ & $\begin{array}{c}\text { Melipona } q . \\
\text { quadrifasciata }\end{array}$ & $\begin{array}{c}\text { Melipona } \\
\text { mandacaia }\end{array}$ & $\begin{array}{l}\text { Melipona } \\
\text { scutellaris }\end{array}$ & $\begin{array}{l}\text { Melipona } \\
\text { subnitida }\end{array}$ \\
\hline Plant Family & Genus & & & & & & & \\
\hline Arecaceae & Cocos sp & - & - & - & - & $0.5 \%(\mathrm{PM})$ & - & - \\
\hline Convolvulaceae & Jacquemontia sp & - & - & - & - & - & $2.74 \%(\mathrm{PM})$ & - \\
\hline Euphorbiaceae & Croton ssp & $16.76 \%$ (PS) & - & $15.4 \%$ (PS) & - & $15.78 \%(\mathrm{PS})$ & - & - \\
\hline Fabaceae & Mimosa ssp & $70.85 \%(P D)$ & - & $50.88 \%(P D)$ & 92.18\% (PD) & $73.89 \%(\mathrm{PD})$ & $61.01 \%(P D)$ & $22.31 \%(\mathrm{PS})$ \\
\hline Melastomatoceae & Clidemia ssp & $3.75 \%(\mathrm{PI})$ & - & $15.47 \%(\mathrm{PS})$ & - & - & - & - \\
\hline Myrtaceae & Myrciassp & - & $22.49 \%$ (PS) & - & - & $9.79 \%(\mathrm{PI})$ & $9.25 \%(\mathrm{PI})$ & $62.59 \%(\mathrm{PD})$ \\
\hline Phytolaccaceae & Microtea ssp & - & - & - & - & - & - & $0.77 \%(\mathrm{PM})$ \\
\hline Plantaginaceae & Angelonia ssp & - & - & - & - & - & - & $14.33 \%(\mathrm{PI})$ \\
\hline Rubiaceae & Mitracarpus ssp & - & - & $12.74 \%(\mathrm{PI})$ & - & - & $5.74 \%(\mathrm{PI})$ & - \\
\hline Solanaceae & Solanun ssp & - & $71.66 \%(\mathrm{PD})$ & - & - & - & - & - \\
\hline Tilaceae & Triumfettas ssp & $3.3 \%(\mathrm{PI})$ & - & - & $5.6 \%(\mathrm{PI})$ & - & - & - \\
\hline Undetermined 1 & & $2.3 \%(\mathrm{PM})$ & $2.85 \%(\mathrm{PM})$ & $2.13 \%(\mathrm{PM})$ & $1.32 \%(\mathrm{PM})$ & - & $2.79 \%(\mathrm{PM})$ & - \\
\hline Undetermined 2 & & $3 \%(\mathrm{PM})$ & $2.9 \%(\mathrm{PM})$ & $1.03 \%(\mathrm{PM})$ & $0.24 \%(\mathrm{PM})$ & - & $2.72 \%(\mathrm{PM})$ & - \\
\hline Total Frequency & & $100 \%$ & $100 \%$ & $100 \%$ & $100 \%$ & $100 \%$ & $100 \%$ & $100 \%$ \\
\hline
\end{tabular}


Table 4. Microorganisms identified in honey from stingless bees.

\begin{tabular}{|c|c|c|c|c|c|c|c|}
\hline \multirow[b]{2}{*}{ Bacteria } & \multicolumn{7}{|c|}{ Species } \\
\hline & $\begin{array}{c}\text { Melipona } \\
\text { asilvai }\end{array}$ & $\begin{array}{c}\text { Melipona } \\
\text { q.anthidioides }\end{array}$ & $\begin{array}{c}\text { Melipona } \\
\text { compressipes }\end{array}$ & $\begin{array}{c}\text { Melipona q. } \\
\text { quadrifasciata }\end{array}$ & $\begin{array}{c}\text { Melipona } \\
\text { mandacaia }\end{array}$ & $\begin{array}{l}\text { Melipona } \\
\text { scutellaris }\end{array}$ & $\begin{array}{l}\text { Melipona } \\
\text { subnitida }\end{array}$ \\
\hline Bacillus ssp & + & + & + & + & + & + & - \\
\hline Klebsiella pneumonia & - & - & - & - & + & - & - \\
\hline Micrococcus ssp & - & - & - & - & - & - & + \\
\hline Neisseria ssp & - & - & - & - & - & - & + \\
\hline Tsukamurella ssp & - & - & - & - & - & - & + \\
\hline \multicolumn{8}{|l|}{ Yeast and Molds } \\
\hline Aspergillus ssp & - & + & + & - & - & + & - \\
\hline Candida apícola & + & - & - & - & - & - & + \\
\hline Eurotiales ssp & - & - & - & - & - & + & - \\
\hline Eutypella ssp & - & + & - & - & - & - & - \\
\hline Penicillium ssp & - & + & - & + & + & - & - \\
\hline Starmerella meliponinorum & - & - & - & - & + & - & - \\
\hline Trametes ssp & - & - & - & - & - & - & + \\
\hline
\end{tabular}

+ Positive in the honey sample / - Negative in the honey sample.

\section{Conclusions}

The honey samples showed important nutritional and therapeutic properties, and high antioxidant capacity. Good levels of reducing sugar content and low protein levels help to keep the balance of microbiota in honeys, confirming the product quality. Few published articles analyzing above mentioned properties are available for Melipona honey. Moreover in Brazil no laws are laid out to asses its quality. This study can thus serve as an important reference for future studies relating to the honey produced by stingless bees.

\section{Acknowledgements}

We thank "Conselho Nacional de Desenvolvimento Científico e Tecnológico (CNPq)" and "Coordenação de Aperfeiçoamento de Pessoal de Nível Superior (CAPES)” for financial support.

\section{References}

Ahn, M., Kumazawa, S., Usui, Y., Nakamura, J., Matsuka, M., Zhu, F., \& Nakayama, T. (2007). Antioxidant activity and constituents of propolis collected in various areas of China. Food Chemistry, 101(4), 1400-1409. http://dx.doi.org/10.1016/j.foodchem.2006.03.045.

Al-Hind, R. R. (2005). Microbiological quality and safety of some "honey pastes" marketed in Jeddah, Saudi Arabia. Umm Al-Qura University Journal ofScience Medicine Enginnering, 17(2), 113-119.

Alvarez-Suarez, J. M., Gonzalez-Paramas, A. M., Santos-Buelga, C., \& Battino, M. (2010). Antioxidant characterization of native monofloral Cuban honeys. Journal of Agricultural and Food Chemistry, 58(17), 9817-9824. PMid:20701246. http://dx.doi.org/10.1021/jf1018164.

Alves, R. M. O., Carvalho, C. A. L., Souza, B. A., Sodré, G. S., \& Marchini, L. C. (2005). Características físico-químicas de amostras de mel de Melipona mandacaia Smith (Hymenoptera: Apidae). Ciência e Tecnologia de Alimentos, 25(4), 644-650. http://dx.doi.org/10.1590/ S0101-20612005000400004.

American Association of Cereal Chemists - AACC. (2000). Approved method of the AACC (9th ed., Method 60-80). St. Paul: AACC.
Andrade, P., Ferreres, F. E., \& Amaral, M. T. (1997). Analysis of honey phenolic acids by HPLC, its application to honey botanical characterization. Journal of Liquid Chromatography \& Related Technologies, 20(14), 2281-2288. http://dx.doi.org/10.1080/10826079708006563.

Anklam, E. (1998). A review of the analytical methods to determine the geographical and botanical origin of honey. Food Chemistry, 63(4), 549-556. http://dx.doi.org/10.1016/S0308-8146(98)00057-0.

Association of Official Analytical Chemists - AOAC. (1995). Official methods of analysis the Association of Official Analytical Chemists (16th ed., Method 991). Arlington: AOAC.

Barth, O. M. (1989). Opólen no mel brasileiro. (pp. 150). Rio de Janeiro: Luxor.

Barth, O. M. (2004). Melissopalynology in Brazil: a review of pollen analysis of honeys, propolis and pollen loads of bees. Scientia Agrícola, 61: 342-350.

Bellemain, E., Carlsen, T., Brochmann, C., Coissac, E., Taberlet, P., \& Kauserud, H. (2010). ITS as an environmental DNA barcode for fungi: an in silico approach reveals potential PCR biases. BMC Microbiology, 10(1), 189. PMid:20618939. http://dx.doi. org/10.1186/1471-2180-10-189.

Beretta, G., Granata, P., Ferrero, M., Orioli, M., \& Facino, R. M. (2005). Standardization of antioxidant properties of honeu by a combination of spectrophotometric/ fluorimetric assays and chemometrics. Analytica Chimica Acta, 533(2), 185-191. http://dx.doi.org/10.1016/j. aca.2004.11.010.

Brand-Williams, W., Cuvelie, M. E., \& Berset, C. (1995). Use of a free radical method to evaluate antioxidant activity. Food Scienc and Technology, 28, 25-30.

Chen, A. Y., \& Chen, Y. C. (2013). A review of the dietary flavonoid, kaempferolon human health and cancer chemo prevention. Food Chemistry, 138(4), 2099-2107. PMid:23497863. http://dx.doi. org/10.1016/j.foodchem.2012.11.139.

Cimpoiu, C., Hosu, A., Miclaus, V., \& Puscas, A. (2013). Determination of the floral origin of some romanian honeys on the basis of physical and biochemical properties. Spectrochimica Acta. Part A: Molecular and Biomolecular Spectroscopy, 100, 149-154. PMid:22579329. http:// dx.doi.org/10.1016/j.saa.2012.04.008.

Dang, Q., Song, W., Xu, D., Ma, Y., Li, F., Zeng, J., Zhu, G., Wang, X., Chang, L.S., He, D., \& Li L. (2015). Kaempferol suppresses bladder 
cancer tumor growth by inhibiting cell proliferation and inducing apoptosis. Molecular Carcinogenesis, 54(9), 831-840. PMid:24700700.

Erdtman, G. (1952). Pollen morphology and plant taxonomy: angiosperms (pp. 537). Stockholm: Almqvist and Wiksell.

Ferreres, F., Andrade, P., \& Tomas-Barberan, F. A. (1996). Natural occurrence of abscisic acid in heather honey and floral nectar. Journal of Agricultural and Food Chemistry, 44(8), 2053-2056. http://dx.doi. org/10.1021/jf9507553.

Franco, B. D. G. M., \& Landgraf, M. (2008). Microbiologia dos alimentos (pp.182). São Paulo: Atheneu.

Giraldo, A. M. V. A., Costa, V. L. M., \& Gallego, R. Z. (2013). Physicochemical and microbiological characterization of Apis Mellifera sp. honey from showest of Antioquia in Colombia. Ingenieria y Ciencia, 9(18), 61-74. http://dx.doi.org/10.17230/ingciecia.9.18.3.

Kadri, S. M., Zaluski, R., Lima, G. P. P., Mazzafera, P., \& Orsi, R. O. (2016). Characterization of Coffea arabica monofloral honey from Espírito Santo, Brazil. Food Chemistry, 203, 252-257. PMid:26948612. http://dx.doi.org/10.1016/j.foodchem.2016.02.074.

Kenjeric, D., Mandic, M. L., Primorac, L., \& Cacic, F. (2008). Flavonoid pattern of sage (Salvia offinalis L.) uniforal honey. Food Chemistry, 110(1), 187-192. PMid:26050182. http://dx.doi.org/10.1016/j. foodchem.2008.01.031.

Kukongviriyapan, V., Phromsopha, N., Tassaneeyakul, W., Kukongviriyapan, L., Sripa, B., Hahnvajanawong, V., \& Bhudhisawasdi, V. (2006). Inhibitory effects of polyphenolic compounds on human arylamine $\mathrm{N}$-acetyltransferase 1 and 2. Xenobiotica, 36(1), 15-28. PMid:16507510. http://dx.doi.org/10.1080/00498250500489901.

Kulisic, T., Dragovic-Uzelac, V., \& Milos, M. (2006). Antioxidant activity of aqueous tea infusions prepared from oregano, thyme and wild thyme. Food Technology and Biotechnology, 44(4): 485-492.

Kumul, R. C., Ruiz, J. C. R., Vásquez, E. O., \& Campos, M. R. S. (2015). Potencial antioxidante de la miel de Melipona beecheii y su relación con la salud: una revisión. Nutricion Hospitalaria, 32(4), 1432-1442. PMid:26545502.

Lane, D. J. (1991). 16S/23S rRNA sequencing. In E. Stackebrandt \& M. Goodfellow (Eds.), Nucleic acid techniques in bacterial systematics (pp. 115-175). New York: John Wiley and Sons.

Liu, J. R., Ye, Y. L., Lin, T. Y., Wang, Y. W., \& Peng, C. C. (2012). Effect of floral sources on the antioxidant, antimicrobial, and anti-inflammatory activities of honeys in Taiwan. Food Chemistry, 139(1-4), 938-943. PMid:23561193. http://dx.doi.org/10.1016/j.foodchem.2013.02.015.

Louveaux, J., Maurizio, A., \& Vorwohl, G. (1978). Methods of Melissopalynology. Bee World, 59(4), 139-157. http://dx.doi.org/1 0.1080/0005772X.1978.11097714.

Meda, A., Lamien, C. E., Romito, M., Millogo, J., \& Nacoulma, O. G. (2005). Determination of the total phenolic, flavonoid and proline contents in Burkina Fasan honey, as well as their radical scavenging activity. Food Chemistry, 91(3), 571-577. http://dx.doi.org/10.1016/j. foodchem.2004.10.006.

Mohammed, S. E., Kabashi, A. S., Koko, W. S., \& Azim, M. K. (2015). Antigiardial activity of glycoproteins and glycopeptides from Ziziphus honey. Natural Product Research, 29(22), 2100-2102. PMid:25587739. http://dx.doi.org/10.1080/14786419.2014.986659.

Moreira, M., Noschang, J., Neiva, I. F., Carvalho, Y., Higuti, I. H., \& Vicente, V. A. (2010). Methological variations in the isolation of genomic from Streptococcus bacteria. Brazilian Archives of Biology and Tecnhology, 53(4), 845-849.

Moskwa, J., Borawska, M. H., Markiewicz-Zukowska, R., PuscionJakubik, A., Naliwajko, S. K., Socha, K., \& Soroczynska, J. (2014). Polish natural bee honeys are anti-proliferative and anti-metastatic agents in human glioblastoma multiforme U87MG cell line. PLoS
One, 4(3), e90533. PMid:24594866. http://dx.doi.org/10.1371/ journal.pone.0090533.

Muhammad, A., Odunola, O. A., Gbadegesin, M. A., Adegoke, A. M., Olugbami, J. O., \& Uche, N. S. (2015). Modulatory role of Acacia honey from north-west Nigeria on sodium arsenite-induced clastogenicity and oxidative stress in male Wistar rats. Natural Product Research, 29(4), 321-326. PMid:25105348. http://dx.doi.org/10.1080/14786 419.2014.940945.

Muniz, F. H., \& Brito, E. R. (2007). Levantamento da flora apícola do município de Itapecuru-Mirim, Maranhão. Revista Brasileira de Biociências, 5, 111-113.

Nishio, E. K., Ribeiro, J. M., Oliveira, A. G., Andrade, C. G. T. J., Proni, E. A., Kobayashi, R. K. T., \& Nakazato, G. (2014). Antibacterial synergic effect of honey from two stingless bees: Scaptotrigon abipunctata Lepeletier, 1836 and S. postica Latreille, 1807. Scientific Reports, 6, 1-8.

Noor, N., Sarfraz, R. A., Ali, S., \& Shahid, M. (2014). Antitumour and antioxidant potential of some selected Pakistani honeys. Food Chemistry, 143, 362-366. PMid:24054252. http://dx.doi.org/10.1016/j. foodchem.2013.07.084.

Różańska, H., \& Osek, J. (2012). Effect of storage on microbiological quality of honey. Bulletin of the Veterinary Institute in Pulawy, 56(2), 161-163. http://dx.doi.org/10.2478/v10213-012-0029-x.

Silva, I. A. A., Silva, T. M. A., Camara, N. Q., Magnani, M., Novais, J. S., Soledade, L. E. B., Lima, E. O., Souza, A. L., \& Souza, A. G. (2013b). Phenolic profile, antioxidant activity and palynological analysis of stingless bee honey from Amazonas, Northern Brazil. Food Chemistry, 141(4), 3552-3558. PMid:23993520. http://dx.doi. org/10.1016/j.foodchem.2013.06.072.

Silva, N., Junqueira, V., Christina, A., Silveira, N. F. A., Taniwaki, M. H., Santos, R. F. S., \& Gomes, R. A. R. (2010). Manual de métodos de análise microbiológica de alimentos e água (4. ed.). São Paulo: Livraria Varela.

Silva, T. M. S., Santos, F. S., Evangelista-Rodrigues, A., Silva, S. E. M., Silva, G. S., Novais, J. S., Santos, F. A. R., \& Camara, C. A. (2013a). Phenolic compounds, melissopalynological, physicochemical analysis andantioxidant activity of jandaíra (Melipona subnitida) honey. Journal of Food Composition and Analysis, 29(1), 10-18. http://dx.doi.org/10.1016/j.jfca.2012.08.010.

Staden, R., Judge, D. P., \& Bonfield, J. K. (2001). Sequence assembly and finishing methods. Methods of Biochemical Analysis, 43, 303322. PMid:11449730. http://dx.doi.org/10.1002/0471223921.ch13.

Tamura, K., Dudley, J., Nei, M., \& Kumar, S. (2007). MEGA4: Molecular Evolutionary Genetics Analysis (MEGA) software versão 4.0. Molecular Biology and Evolution, 24(8), 1596-1599. PMid:17488738. http://dx.doi.org/10.1093/molbev/msm092.

Tominaga, Y., Kobayachi, Y., Goto, T., Kasemura, K., Nomura, M., \& Yasshi, Y. (2005). DPPH Radical-scavenging effect of several phenylpropanoid compounds and their glycoside derivatives. Journal of the Pharmaceutical Society of Japan, 125(4), 371-375. PMid:15802883.

Torres-González, A., López-Rivera, P., Duarte-Lisci, G., López-Ramirez, Á., \& Correa-Betinez, A. (2016). Analysis of volatile componentes from Melipona beecheii geopropolis from Shoutheast Mexico by headspace solid-phase microextration. Natural Product Research, 30(2), 237-240. PMid:26118891. http://dx.doi.org/10.1080/14786 419.2015.1043631.

Zheng, S., Ma, Z., Han, H., Ye, J., Wang, R., Cai, S., Zhou, H., Yu, L., Zeng, S., \& Jiang, H. (2014). Post-column mobile phase adjustment: a strategy to eliminate the contradiction between liquid chromatography and mass spectrometry in the determination of flavonoids in rat plasma. Journal of Pharmaceutical and Biomedical Analysis, 95, 176183. PMid:24675072. http://dx.doi.org/10.1016/j.jpba.2014.02.024. 